\title{
A Functional Connection between the Circadian Clock and Hormonal Timing in Arabidopsis
}

\author{
Manjul Singh ${ }^{1}$ (1) and Paloma Mas ${ }^{1,2, *}$ \\ 1 Center for Research in Agricultural Genomics (CRAG), Consortium CSIC-IRTA-UAB-UB, Campus UAB, \\ Bellaterra, 08193 Barcelona, Spain; manjul.singh@cragenomica.es \\ 2 Consejo Superior de Investigaciones Científicas, 08028 Barcelona, Spain \\ * Correspondence: paloma.mas@cragenomica.es
}

Received: 15 October 2018; Accepted: 20 November 2018; Published: 23 November 2018

\begin{abstract}
The rotation of the Earth entails changes in environmental conditions that pervasively influence an organism's physiology and metabolism. An internal cellular mechanism known as the circadian clock acts as an internal timekeeper that is able to perceive the changes in environmental cues to generate 24-h rhythms in synchronization with daily and seasonal fluctuations. In plants, the circadian clock function is particularly important and regulates nearly every aspect of plant growth and development as well as proper responses to stresses. The circadian clock does not function in isolation but rather interconnects with an intricate network of different pathways, including those of phytohormones. Here, we describe the interplay of the circadian clock with a subset of hormones in Arabidopsis. The molecular components directly connecting the circadian and hormone pathways are described, highlighting the biological significance of such connections in the control of growth, development, fitness, and survival. We focus on the overlapping as well as contrasting circadian and hormonal functions that together provide a glimpse on how the Arabidopsis circadian system regulates hormone function in response to endogenous and exogenous cues. Examples of feedback regulation from hormone signaling to the clock are also discussed.
\end{abstract}

Keywords: circadian clock; phytohormones; growth and development; Arabidopsis thaliana

\section{Circadian Clock Function in Arabidopsis thaliana}

The circadian clockwork relies on the integration of multiple components and regulatory mechanisms that ultimately results in 24-h biological oscillations [1,2]. Research in Arabidopsis thaliana has provided a glance at how the clock is functioning. Studies in other plant species are also helping us understand the degree of conservation and how the clock has evolved during evolution $[3,4]$ The classical and most simple description of the circadian function includes a central oscillator that generates rhythms in biological processes or outputs [5] that are reset every day by the environmental cues through the function of the input pathways [6].

In relation to the circadian outputs, the circadian clock regulates a wide variety of processes in plants [7] including, among others, photosynthesis, cell cycle, flowering time, or stress responses. Analyses of mutant plants in which the clock lacks synchrony with the 24-h external time show that circadian timing by the clock has an adaptive advantage [8-10]. Furthermore, plants with internal clocks that match the external diurnal cycle show increased photosynthetic efficiency and better fitness compared to those plants whose clocks are not in synchrony with the environment [11]. The circadian clock also enables plants to regulate the magnitude of the response to a stimulus at the time of day that is more appropriate. This phenomenon is known as circadian gating and not only regulates the timing of the responses but also ensures a proper allocation of resources for improved fitness and survival. 
The clock outputs are directly or indirectly regulated by a number of components that are closely related to the central oscillator. The oscillator components regulate each other in a complex network that generates the rhythms through their own expression and function [12] (Figure 1). These oscillations are translated into rhythms of multiple pathways controlled by the clock [13]. The first components described to be part of the Arabidopsis oscillator included the LATE ELONGATED HYPOCOTYL (LHY) and CIRCADIAN CLOCK ASSOCIATED1 (CCA1) MYB-like transcription factors as morning-expressed components $[14,15]$ that repressed the expression of the evening-expressed pseudo response regulator (PRR) TIMING OF CAB EXPRESSION1/PSEUDO RESPONSE REGULATOR1 (TOC1/PRR1) gene [16,17]. In turn, TOC1 was found to repress not only CCA1 and LHY expression [18-20] but also nearly all the components of the oscillator network [20]. CCA1 and LHY also regulate other members of the PRR family including PRR9, PRR7, and PRR5 [21]. The PRR protein family represses, in turn, the expression of CCA1 and $L H Y[21,22]$. The repressive function of PRRs is alleviated through the activity of the evening complex (EC), which comprises EARLY FLOWERING 3 (ELF3), ELF4, and LUX ARRHYTHMO/PHYTOCLOCK1 (LUX/PCL1) [23,24]. This results in repression of PRR7 and PRR9, which allows the onset of LHY and CCA1 at dawn, initiating the cycle again. Mathematical modelling prediction and experimental validation proved the involvement of GIGANTEA (GI), an evening expressed gene, to form an additional negative feedback loop with TOC1 [25]. Indeed, TOC1 protein stability is regulated by the proteasomal pathway through interaction with the F-box photoreceptor ZEITLUPE (ZTL) [26]. Later studies also showed that PRR5 is regulated in a similar fashion [27]. The mode of GI function relies on the light-dependent interaction with ZTL to control its stability, and thus modulating TOC1 protein turn-over [28].

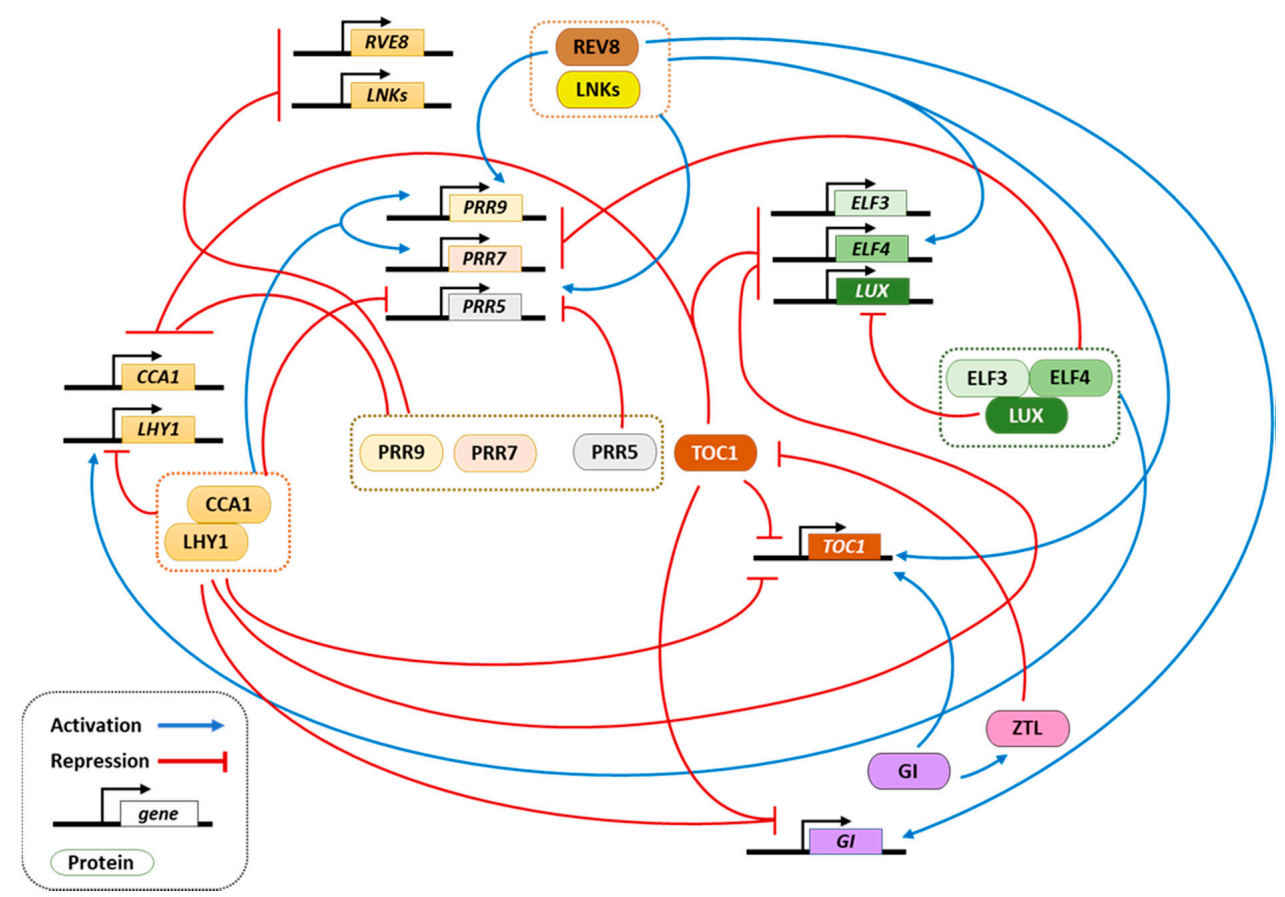

Figure 1. Scheme representing the network of regulatory loops at the core of the circadian oscillator in Arabidopsis thaliana. Rectangles denote genes while ovals represent proteins. Blue arrows indicate activation, and red lines ending in perpendicular dashes indicate repression. The scheme illustrates the complexity of the network, although it does not include all of the oscillator components. LHY: LATE ELONGATED HYPOCOTYL; CCA1: CIRCADIAN CLOCK ASSOCIATED1; PPR: PSEUDO RESPONSE REGULATOR; TOC1: TIMING OF CAB EXPRESSION1; ELF3: EARLY FLOWERING 3; ELF4: EARLY FLOWERING 4; LUX: LUX ARRHYTHMO; LNK: NIGHT LIGHT-INDUCIBLE AND CLOCK-REGULATED; RVE8: REVEILLE8; ZTL: ZEITLUPE; GI: GIGANTEA 
A regulatory mechanism associated with clock gene expression involves changes in chromatin conformation. Indeed, activating chromatin marks have been shown to oscillate at the promoters of clock genes [29], and this rhythmic accumulation correlates with the circadian waveforms of the expressed genes. The authors proposed that chromatin modifications might act as positive activating marks favoring the transcription of the genes. This activation is relevant as the oscillator network is full of repressors. Some of the plant chromatin remodeling components and circadian clock transcription factors involved in this regulation have been discovered. For example, CCA1 is able to bind to the TOC1 promoter and this binding correlates with a hypoacetylated state of histone 3 (H3) and the repression of TOC1 mRNA expression $[29,30]$. The single MYB and clock-related component known as REVEILLE8/LHY CCA1 LIKE5 (RVE8/LCL5) promotes the expression of TOC1 and other clock genes through binding to their promoters [30-32]. The activating function of RVE8 favors a hyperacetylation of $\mathrm{H} 3$, thus antagonizing the CCA1 repressive role [30]. The transcriptional activation by RVE8 involves the interaction with the co-activators NIGHT LIGHT-INDUCIBLE AND CLOCK-REGULATED GENES (LNKs), which form a protein complex to activate the transcription of the evening-expressed clock genes [33]. Notably, the PRRs bind to the promoters of LNKs to repress their expression [33,34]. The expression of LNKs is also repressed by the EC in a temperature-dependent manner [35]. Therefore, LNKs integrate light and temperature signals into the circadian clock [36,37]. The mechanism by which RVE8 and LNKs activate circadian gene expression was recently identified and involves the recruitment of the transcriptional machinery to the evening-expressed loci to generate the rhythms in nascent RNAs [38].

\section{Interplay between Auxin and the Circadian Clock}

Auxin (indole-3-acetic acid, IAA) is a key plant hormone involved in the control of an ample range of processes at both short and long distances within the plant. Some of the processes regulated by auxins include tropic responses to light and gravity, root and shoot architecture, organ patterning, vascular development, and growth $[39,40]$. A primary mode of auxin action relies on a rapid change in the expression of hundreds of genes [41]. Transcriptional activation depends upon the binding of AUXIN RESPONSE FACTORS (ARFs) to an auxin-responsive element (ARE) present in the promoters of the auxin-regulated genes $[42,43]$. The mechanism depends on auxin binding to a structural pocket present in the TRANSPORT INHIBITOR RESPONSE1/AUXIN SIGNALING F-BOX (TIR1/AFB) receptor family, which interacts with members of the auxin/indole-3-acetic acid inducible (Aux/IAA) transcriptional repressor family. Aux/IAAs function as transcriptional repressors through the recruitment of the co-repressor TOPLESS (TPL) protein family [44,45]. The auxin-mediated binding of TIR1/AFB to Aux/IAAs results in Aux/IAAs poly-ubiquitination and degradation. As Aux/IAAs interact with the ARFs, poly-ubiquitination and degradation of Aux/IAAs releases the repression at the ARE-containing promoters, which allows the activation of the auxin-responsive genes by ARFs.

Evidence for the connection between auxin and the circadian clock came from early studies arguing a possible role of circadian rhythmicity in polar transport as well as endogenous accumulation of auxin [46,47]. Later genome-wide transcriptomic studies showed that the expression of a subset of genes involved in auxin biosynthesis, perception, and signaling was controlled by the clock [48]. It is noteworthy that the expression of the transcriptional repressors AUX/IAAs and activators ARFs showed anti-phasic oscillations. These anti-phasic transcriptional rhythms suggest that the circadian clock precisely times the function of antagonistic auxin-related components. Later studies showed the possible molecular connection between the clock and auxin. Indeed, the clock regulated MYB-like transcription factor REVEILLE 1 (RVE1) promotes auxin accumulation specifically during the day by activating the expression of YUCCA8 (YUC8), an auxin biosynthetic gene. This regulation fits well with the circadianly gated promotion of hypocotyl growth [49].

A recent study has also shown that lateral root emergence is altered in plants in which the clock is not running properly or when the rhythmic expression of auxin-related targets is disrupted. The authors show that the circadian clock is re-phased during lateral root emergence and controls 
the expression of auxin-related genes [50]. Root meristem size is also regulated by the clock-related component TIME FOR COFFEE (TIC) [51]. The regulation relies on the control of the expression of the PIN-FORMED (PIN) genes which are involved in the distribution of auxin, resulting in low auxin accumulation in the roots of tic mutant plants. Molecular details about the clock-auxin connection have been further identified with the findings that the clock component CCA1 directly binds to the promoter of the ATP-dependent chromatin remodeling gene PICKLE (PKL) to positively regulate its expression [52]. PKL regulates trimethylation of lysine 27 of $\mathrm{H} 3(\mathrm{H} 3 \mathrm{~K} 27 \mathrm{me} 3)$ and activates the expression of INDOLE-3-ACETIC ACID INDUCIBLE 19 (IAA19) and IAA29, which are key for hypocotyl growth at $28{ }^{\circ} \mathrm{C}$ [52]. ELF3 most likely interacts with CCA1 to interfere with the binding to $P K L$ promoter thereby inhibiting CCA1-dependent activation of $P K L$ expression [52].

Recently, individual nucleotide resolution crosslinking and immunoprecipitation (iCLIP) genome-wide studies of the clock-regulated glycine-rich RNA-binding protein AtGRP7 have shown that AtGRP7 regulates, among other targets, the transcripts of DORMANCY/AUXIN ASSOCIATED FAMILY PROTEIN2 (DRM2) [53]. However, the physiological consequences of such regulation remain to be elucidated. Another connection was reported in studies with the clock-regulated PHYTOCHROME-INTERACTING FACTOR 4 (PIF4) gene, which encodes a basic helix-loop-helix transcription factor with a key function in controlling plant growth [54]. PIF4 function seems to rely on the regulation of hormone-related genes. The targets include auxin-associated genes and other genes related to Brassinosteroid (BR), gibberellins (GA), ethylene, and cytokinins (CK). The pif4pif5 mutants are less sensitive to auxin-induced growth, suggesting that auxin mediated growth is partially regulated by PIF4 and PIF5 [55].The authors propose that the circadian clock regulation of growth might be mediated through the circadian regulation of hormone-related genes controlled by PIF4 and PIF5 [55-57]. The interaction of PIF4 with TOC1 has also been shown to be important in the regulation of the expression of the auxin biosynthesis gene YUC8 in the control of hypocotyl growth [58]. Warm temperatures during the day activate PIF4, which in turn activates YUC 8 and promotes hypocotyl elongation. During the evening, TOC1 accumulates and directly inhibits PIF4, and thus suppressing growth [58]. Natural variation studies of ELF3 alleles have recently shown differential integration of temperature and photoperiod information. Furthermore, the authors showed that ELF3-mediated gating of PIF4 expression confers an adaptive advantage in response to environmental cues [59]. Differential regulation of hormone genes might indirectly account for this adaptation.

Auxin signaling was reported to not feedback strongly to the clock as treatment with exogenous auxin has only a minor effect on clock function [48]. However, auxin is important for maintaining the precision of the clock, especially under constant light conditions [60]. Another connection between the circadian clock and auxin came from studies searching for factors important for the dynamic control of circadian period and phase entrainment [61] An Ethyl Methanesulphonate (EMS) mutagenesis screen identified period oversensitive to nicotinamide (son1), which mapped to the BIG gene, encoding a Calossin-like protein required for normal auxin efflux [62]. The son1 mutant has altered adjustability to circadian period in response to nicotinamide [61].

\section{Functional Connection of Cytokinins and the Circadian Clock}

Cytokinins (CKs) are adenine derivatives implicated in the regulation of cell division, shoot and root growth, senescence, phyllotaxis, and embryonic development, among others [63]. CKs were also shown to play a role in plant responses to environmental conditions [64]. The rate-limiting step of CK biosynthesis is catalyzed by isopentenyltransferases (IPTs) [65] while degradation is regulated by cytokinin oxidases/dehydrogenases (CKXs) [66]. Different CK receptors ARABIDOPSIS HISTIDINE KINASE2 (AHK2), AHK3, and CYTOKININ RESPONSE1 (CRE1)/AHK4 with specific properties have been reported [67-69]. CK signaling relies on both the balance between CK synthesis and degradation and a His-Asp phosphorelay mechanism involving ARABIDOPSIS HISTIDINE PHOSPHOTRANSFER PROTEINs (AHPs) and B-type ARABIDOPSIS RESPONSE REGULATORs (ARRs) [70]. The target genes of B-type ARRs also includes A-type ARRs, which act as negative-feedback regulators of CK 
signaling. The A-type ARRs compete with B-type ARRs and directly interact with AHPs for the phosphoryl residue [71].

The crosstalk between the circadian clock and CK signaling is evidenced by several studies. A high fraction of genes regulated by the clock are also regulated by CK [72]. CK-mediated growth responses are also affected in clock mutants [73], suggesting that the clock might directly or indirectly modulate CK signaling. Consistently, in tobacco leaves, CK levels oscillates under diurnal conditions with peak accumulation around midday [74]. A possible molecular connection between the clock and CK signaling was hinted in studies showing that the EC represses the CK-related genes ARR6, ARR7, CYTOKINE OXIDASE5, CYTOKININ RESPONSE FACTOR 4 (CRF4), and CRF5 [75]. It would be interesting to fully explore the mechanistic insights and biological consequences of such regulation. The expression of the Arabidopsis type-A response regulator ARR9 is not only controlled by CK but also by the circadian clock [76]. ARR9 oscillatory expression shows an advanced phase in cca1/lhy/toc1 triple mutant plants [76]. However, the circadian regulation appears to be independent of CK [76], which opens the possibility of a parallel function of ARR9 to its role in CK signaling. The clockand flowering-related component GI has been recently shown to be connected with chloroplast biogenesis [77]. The regulation relies on the interaction of multiple pathways including, among others, those of CK and GA [77]. As mentioned above, the interplay of different hormone pathways and their circadian regulation is also exemplified by studies uncovering PIF4 targets, which include genes related to auxin, BR, GA, ethylene, and CK signaling pathways [56].

Cytokinins signaling might feedback, in turn, to regulate the circadian function. Indeed, treatment with CK delays the circadian phase and induces the expression of CCA1 and $L H Y$ as well as the morning-phased output gene CHLOROPHYLL A/B-BINDING PROTEIN 2 (CAB2) while the same treatment represses TOC1 [60,73]. Most likely, the CK-mediated regulation of circadian gene expression is gated by the clock, as the responses depend on the time-of-day [60]. The regulation is also dose-dependent, as treatment with high and low concentrations of CK renders a delayed and advanced phase, respectively [78]. Circadian responses to some stresses might also rely on proper CK signaling. Extended light treatment induces a circadian stress, and adaptation to this stress requires proper CK signaling [79]. Analyses of arr3/4 mutant plants also revealed changes in circadian period length [78]. Under white light conditions, arr3/4 mutant plants also show a leading phase that might depend upon ARR4 interaction with the light receptor phytochrome B [80]. However, the circadian defects appear to be independent of CK, which again reinforces the idea of parallel functions of ARRs in the clock and in CK signaling.

\section{Timing by the Circadian Clock Controls Plant Responses to Abscisic Acid}

The hormone abscisic acid (ABA) controls key aspects of plant growth and development as well as responses to stressful environments, such as, for instance, drought [81,82]. ABA is synthetized from $\beta$-carotene, and the rate-limiting step of ABA biosynthesis is catalyzed by 9-cis-epoxycarotenoid dioxygenase (NCED) enzymes [83]. Fluctuations in ABA concentration [84] are perceived by a number of ABA receptors [85] that initiate complex signaling cascades to ultimately modulate vegetative and reproductive processes as well as plant tolerance to environmental stresses [86]. One family of receptors include the pyrabactin resistance (PYR)-like (PYL) or regulatory component of ABA receptor (RCAR) [87]. Upon ABA binding to PYL/RCAR receptors, the co-receptor phosphatase 2C (PP2C) is inactivated, releasing its repression on Sucrose nonfermenting 1 -related kinases 2 (SNRK2) that are then activated $[87,88]$. Phosphorylation of ABA-responsive transcription factors by SNRK2 allows their binding to ABA-responsive elements (ABREs) in the promoters of ABA-responsive genes [89,90].

Similar to other hormone pathways, the expression of a significant fraction of ABA-related genes rhythmically oscillate [72,91]. These rhythms are ultimately translated into rhythmic oscillations of ABA accumulation, reaching a peak in the evening [92]. The observed ABA oscillation is in agreement with the rhythmic oscillation of the expression of the ABA receptor, with PYR1/RCAR11 displaying a peak near to dusk [93] (Figure 2). Rhythms are contributed, at least in part, by LHY, which controls the 
rate-limiting step of ABA biosynthesis through repression of NCED enzymes. LHY also binds to the promoters of other ABA-related genes and contributes to the promotion of ABA-responsive genes that increase tolerance to drought and osmotic stress [92].

Genome-wide analyses comparing rhythmic expression networks of watered versus droughted Brassica rapa plants have allowed the identification of early transcriptomic changes related to photosynthesis and stomatal conductance that could be used as efficient indicators of drought even before symptoms appear [94]. It was previously proposed that the circadian clock might gate stomatal closure in the heat of the afternoon when this regulation is more needed [95,96]. A molecular mechanism explaining the ABA gating by the clock was provided in a study involving the putative ABA receptor ABA-RELATED (ABAR) and TOC1 [95] (Figure 2). The study showed that TOC1 binds to the $A B A R$ promoter to repress its expression. This regulation relies on the gated acute induction of TOC1 by ABA, which occurs exclusively during the day but not at night. TOC1 induction by $\mathrm{ABA}$ also relies on the function of ABAR, thus establishing a feedback loop that was shown to be essential for plant responses to drought at midday, a time when temperatures and the possibilities for drought are high. Notably, TOC1 interacts with ABA INSENSITIVE3 (ABI3), which is also involved in ABA signaling [97]. Mathematical modelling has established a model incorporating TOC1 as an environmental sensor, with a dual function modulating both the pace of the clock and the kinetics of plant responses to stress [19].

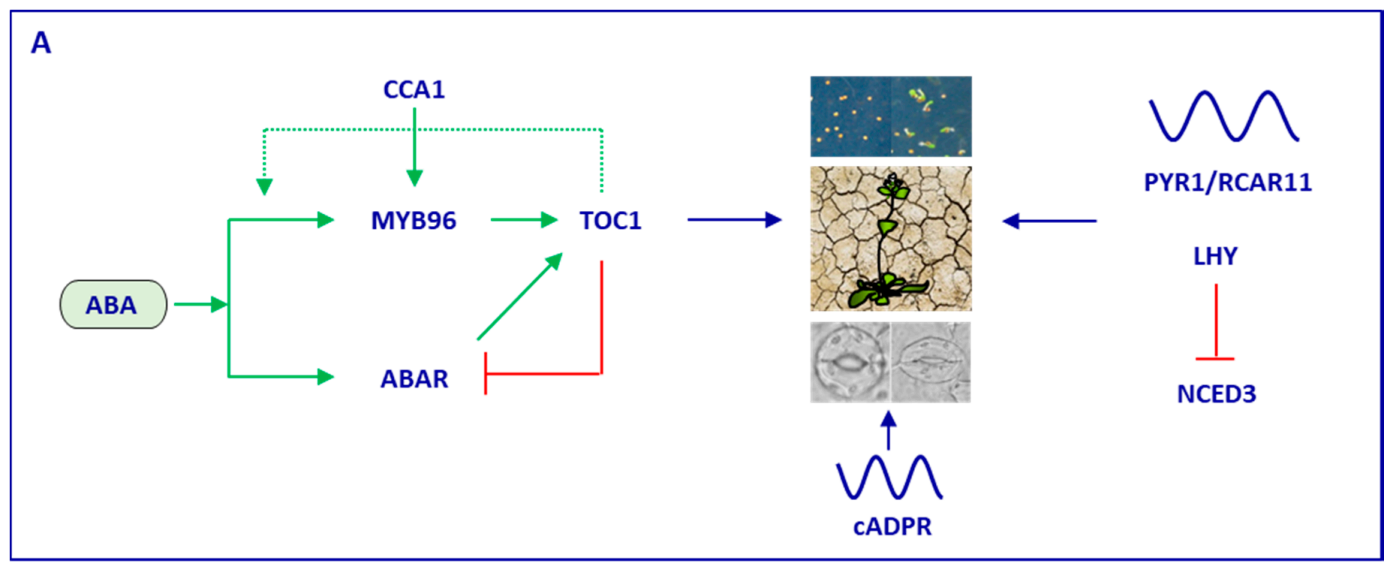

B
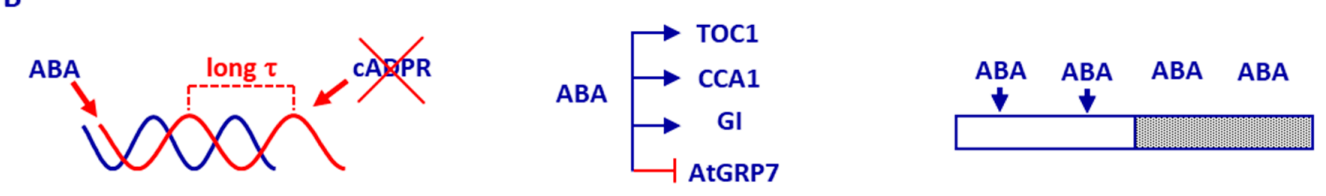

Figure 2. Schematic representation depicting the connection between abscisic acid (ABA) signaling and the circadian clock in Arabidopsis thaliana. (A) A complex network involving the reciprocal regulation between TIMING OF CAB EXPRESSION1 (TOC1) and ABA-RELATED (ABAR) also involves MYB96 and the clock component CIRCADIAN CLOCK ASSOCIATED1 (CCA1; left panel). This network is important in the control of ABA-regulated processes such as germination, plant responses to drought, and stomatal aperture. Rhythms in cyclic adenosine diphosphate ribose (cADPR) also control these processes (middle panel). The expression of many genes including the ABA receptors is controlled by the clock. The circadian component LATE ELONGATED HYPOCOTYL (LHY) plays an important role in this regulation, controlling, for instance, the expression of NCDE3 (right panel); (B) ABA signaling feeds back to the clock by lengthening de internal period of the clock $(\tau)$. The lack of cADPR also leads to alteration of period (left panel). A number of clock genes are regulated by ABA (middle panel) and this regulation was shown in some instances to be gated by the clock, occurring only during the day (right panel). Please consult the text for further details. 
The MYB96 transcription factor contributes to this regulatory mechanism. Indeed, MYB96 activates TOC1 expression through direct binding to the TOC1 promoter. This regulation is important for the gated induction of TOC1 by ABA. In turn, MYB96 is induced by ABA and this induction requires a functional TOC1 [98]. The MYB96-TOC1 reciprocal regulation defines plant tolerance to drought conditions. Notably, CCA1 affects the circadian expression of MYB96 through binding to its promoter. The authors thus identified a molecular mechanism connecting the circadian and stress signaling pathways important under drought conditions [98].

Another circadian-ABA connecting point relies on cyclic adenosine diphosphate ribose (cADPR), a cytosolic ligand that promotes the release of $\mathrm{Ca}^{2+}$ into the cytosol [99]. The clock controls the rhythms of cADPR, but cADPR is also involved in ABA-induced stomatal closure. Consistently, there is a significant overlap between transcripts regulated by cADPR and ABA [100], as well as by cADPR and the circadian clock [99].

Other clock-related components are connected to ABA biosynthesis, signaling, and responses, but the molecular mechanisms behind this connection remain to be discovered. For example, in prr9/prr7/prr5 triple mutant plants, ABA accumulation is increased, as is the expression of genes involved in carotenoid and ABA biosynthetic pathways [101]. Mutant plants of tic show hypersensitivity to oxidative stress and ABA, leading to a significant resistance to drought [102]. PATHOGEN AND CIRCADIAN CONTROLLED 1 (PCC1) is a circadianly-regulated gene involved in defense responses against pathogens. Loss-of-function $p c c 1$ plants were hypersensitive to ABA showing reduced seedling establishment and stomatal aperture [103]. The clock also regulates seed dormancy as its induction was faster in mutant plants of morning-expressed clock genes and delayed when mutants of evening-expressed clock genes were assayed [104]. Consistent with these results, analyses of ccal and lhy mutants also display alterations in seed germination in response to low temperature and dry after-ripening [105]. Analyses of the evening-expressed clock-related atgrp7 mutants showed hypersensitive phenotypes to ABA in both seed germination and root growth assays. These phenotypes were associated with increased expression of two ABA-and stress-inducible genes, RD29A and RAB18 [106].

The abscisic acid signaling seems to feed back to the clock. Indeed, exogenous treatment with ABA lengthens the circadian period in a process that seems to be light-dependent [60]. Furthermore, inhibition of cADPR synthesis lengthened the period of the clock and its outputs [99]. As mentioned above, ABA also acutely induces the expression of TOC1 [95] while ABA represses AtGRP7 expression [106]. CCA1 expression is induced by dry after-ripening, and after-ripening alters the transcriptional amplitude of clock gene oscillations [105]. Physiological and genetic studies have also shown that ABA regulates the GI pathway to activate florigen genes under drought condition [107].

\section{Interconnection between Ethylene Signaling and the Circadian Clock}

Ethylene is a small gaseous hormone that can freely diffuse across membranes and permits plant-to-plant communication. The function of ethylene in defense responses has been extensively reported [108,109], while its role in growth and yield under abiotic stress has been also recently recognized [110]. Ethylene facilitates fruit ripening and controls plant growth in a light- and nutrient-dependent manner [111-113]. Ethylene is synthesized from methionine, which is converted first into S-adenosyl methionine and then into 1-aminocyclopropane-1-carboxylic acid (ACC), the precursor of ethylene. The ACC-synthases control the rate-limiting step in ethylene synthesis. The ethylene receptors ETHYLENE RESPONSE SENSOR 1 (ERS1), ERS2, ETHYLENE RESISTANCE 1 (ETR1), ETR2 and ETHYLENE INSENSITIVE 4 (EIN4) are active in the absence of ethylene, which bind to the CONSTITUTIVE TRIPLE RESPONSE 1 (CTR1) protein [114]. Accumulation of ethylene targets the receptors and CTR1 to degradation through the proteasome pathway [115]. As CTR1 represses EIN2, accumulation of ethylene releases EIN2 repression resulting in ethylene responsive regulation of the translation of F-box proteins ETHYLENE INSENSITIVE3 BINDING F-BOX1 (EBF1) and EBF2, which feeds back into the regulation of EIN3 and EIN3-LIKE 1 (EIL1). EIN3 and EIL1 induces the 
expression of several secondary transcription factors named ETHYLENE RESPONSE FACTOR (ERFs) involved in the control of ethylene signaling outputs [116,117].

Although fewer studies report the interplay between the circadian clock and ethylene signaling, there are nonetheless some examples that evidence this correlation. For instance, the circadian clock seems to regulate the oscillations of ethylene emission, which display a peak at midday. This regulation occurs through the control of the expression of the ethylene precursor ACC SYNTHASE (ACS) genes. In particular, ethylene production correlates with ACS8 expression, which is controlled by light, the circadian clock, as well as by a negative feedback with ethylene signaling [118]. Another example includes XAP5 CIRCADIAN TIMEKEEPER (XCT), which is a circadianly regulated gene that encodes a protein involved in small RNA biogenesis, down-stream of ETHYLENE-INSENSITIVE3 (EIN3) [119]. $\mathrm{XCT}$ has been recently shown to be involved in disease resistance, which opens the possibility of a circadian and ethylene regulation of plant immunity through XCT [120].

Ethylene-related genes are down-regulated in Arabidopsis interspecific hybrids. Treatment with ethylene abolishes vigor in F1 hybrids, and consistently, mutant plants of a gene encoding the rate-limiting ethylene biosynthesis enzyme ACS show increased biomass vigor. A recent report has shown that ACS expression is regulated by CCA1 during the day and by the light and circadian basic loop-helix-loop transcription factors PIF5 at night, providing a mechanism by which circadian rhythms, light signaling, and ethylene production are integrated in the control of biomass heterosis [121].

In relation to the effects of ethylene on the circadian function, mutants of ethylene signaling do not show a clear alteration of circadian phase or period [118]. However, other studies have shown that ethylene actually shortens the circadian period [122] in an antagonistic fashion with sucrose [122]. Furthermore, in the dark, circadian rhythms are sustained by sucrose through the stabilization of the GI protein in a process involving the negative regulator of ethylene signaling CTR1 [122].

\section{Circadian Gating of Gibberellin Signaling by the Clock}

Gibberellins (GAs) are phytohormones belonging to a large family of diterpenoids. GAs regulate seed germination, hypocotyl elongation, leaf expansion, flowering, and fruit and seed development [123]. GA signaling relies on the DELLA protein repressors belonging to the GRAS family of transcriptional regulators [124]. The DELLA proteins include GA INSENSITIVE (GAI), REPRESSOR OF ga1-3 (RGA), RGA-LIKE1 (RGL1), RGL2, and RGL3, [125]. In the absence of GA, DELLA proteins inhibit the transcription of GA-responsive genes [126,127]. However, GA binding to the receptor GA INSENSITIVE DWARF1 (GID1) [128] promotes the interaction of GID1 with the DELLA proteins, triggering their degradation via the proteasome pathway [129]. This signaling cascade ultimately results in the regulation of the expression of genes involved in cell expansion and division, floral induction, inhibition of seed germination, and responses to environmental stress.

Several studies have shown the link between the clock and GA. Indeed, GA signaling oscillates due to a precise transcriptional circadian regulation of the GA receptors. This regulation stabilizes DELLA proteins during the day and provides higher sensitivity to GA at night, a gating control that is important for rhythmic growth [130]. The expression of the GA biosynthetic genes GA20ox1 and GA20ox2 is up-regulated in elf3 mutant plants. The growth phenotypes of elf3 mutants result from altered GA biosynthesis that in turn affects PIF4 and PIF5 activity. It is interesting that similar results were reported in barley, indicating that the regulation of GA biosynthesis by ELF3 in the control of growth is conserved in eudicots and monocots [131]. Analyses of cca1 mutants showed that these plants are hyposensitive to GA, a phenotype that molecularly correlates with the interaction of CCA1 with the DELLA protein RGA. The MUT9p-LIKE KINASE1 (MLK1) and MLK2 kinases that phosphorylate Histone 3 were also found to interact with RGA, antagonizing its binding with CCA1 and thus providing a mechanism to control the expression of cell elongation-related target genes [132]. SPINDLY (SPY), a negative regulator of GA signaling, interacts with GI and this interaction seems to be important in the control of flowering time, circadian cotyledon movements, and hypocotyl elongation [133]. As mentioned above, this interaction might be also important in the control of 
chloroplast biogenesis [77]. The circadian clock is also important in the regulation of ABA- and GA-related gene expression in seeds. Both GI and TOC1 appear to have a relevant function controlling seed responses to ABA and GA [105]. Clock function might not be significantly affected by GA [60,130], but GA signaling might feedback to clock outputs as it mediates the oscillatory expression of many clock-regulated genes related to biotic and abiotic stresses and cell wall modification [130].

\section{Perspectives}

The interplay between the circadian clock and hormone signaling pathways exemplifies an efficient way by which plants can integrate endogenous and exogenous cues to regulate growth, development, and responses to stress. The studies described here, and others not included due to space constraints, demonstrate the relevance of proper timing of hormone function. Despite the current knowledge, we are far from a complete understanding of all the components connecting these pathways. Identifying additional components and their mechanisms of action will be important to fully decipher the signaling networks connecting the clock with hormones. Furthermore, tissue-specific studies are uncovering particular circadian functions in separate parts of the plant. Tissue- and/or cell-specificity of hormone function and interaction with the clock might be important in expanding our view of the biological significance of their interactions. Likewise, transcriptional regulation and protein phosphorylation and degradation are common regulatory mechanisms underlying the hormone and circadian inner-work. Additional future studies focused on chromatin modifications will provide insightful information about how changes in chromatin conformation modulate the circadian and hormonal functions. Lastly, although we did not cover it in this review, a wealth of information is available for hormone function in crops of agronomical interest. Integrating the information from the model system Arabidopsis together with that already obtained with crops will help us in elaborating an efficient toolbox to improve crop growth, fitness, and survival at a time when global climate change is compromising the food supply for an ever-increasing human population.

Funding: This research was funded by the Spanish Ministry of Economy and Competitiveness, grant number BFU2016-77236-P; by the Generalitat de Catalunya (AGAUR), grant number 2017 SGR 01211 and by the CERCA Program/Generalitat de Catalunya. We acknowledge financial support from the Spanish Ministry of Economy and Competitiveness through the "Severo Ochoa Program for Centers of Excellence in R\&D" 2016-2019, grant number SEV-2015-0533. M.S. is supported by a post-doctoral fellowship from the Severo Ochoa Program.

Acknowledgments: We thank members of P. Mas laboratory for useful comments on the review. We apologize to those colleagues whose work was not included here due to space constraints.

Conflicts of Interest: The authors declare no conflict of interest.

\section{References}

1. Sanchez, S.E.; Kay, S.A. The plant circadian clock: From a simple timekeeper to a complex developmental manager. Cold Spring Harbor Perspect. Biol. 2016. [CrossRef] [PubMed]

2. Greenham, K.; McClung, C.R. Integrating circadian dynamics with physiological processes in plants. Nat. Rev. Genet. 2015, 16, 598-610. [CrossRef] [PubMed]

3. McClung, C.R. Beyond Arabidopsis: The circadian clock in non-model plant species. Semin. Cell Dev. Biol. 2013, 24, 430-436. [CrossRef] [PubMed]

4. Anwer, M.U.; Davis, S.J. An overview of natural variation studies in the Arabidopsis thaliana circadian clock. Semin. Cell Dev. Biol. 2013, 24, 422-429. [CrossRef] [PubMed]

5. Nagel, D.H.; Kay, S.A. Complexity in the wiring and regulation of plant circadian networks. Curr. Biol. 2012, 22, R648-R657. [CrossRef] [PubMed]

6. Mas, P.; Yanovsky, M.J. Time for circadian rhythms: Plants get synchronized. Curr. Opin. Plant Biol. 2009, 12, 574-579. [CrossRef] [PubMed]

7. Millar, A.J. The intracellular dynamics of circadian clocks reach for the light of ecology and evolution. Annu. Rev. Plant Biol. 2016, 67, 595-618. [CrossRef] [PubMed]

8. Ouyang, Y.; Andersson, C.R.; Kondo, T.; Golden, S.S.; Johnson, C.H. Resonating circadian clocks enhance fitness in Cyanobacteria. Proc. Natl. Acad. Sci. USA 1998, 95, 8660-8664. [CrossRef] [PubMed] 
9. Green, R.M.; Tingay, S.; Wang, Z.-Y.; Tobin, E.M. Circadian rhythms confer a higher level of fitness to Arabidopsis plants. Plant Physiol. 2002, 129, 576-584. [CrossRef] [PubMed]

10. Michael, T.P.; Salomé, P.A.; Hannah, J.Y.; Spencer, T.R.; Sharp, E.L.; McPeek, M.A.; Alonso, J.M.; Ecker, J.R.; McClung, C.R. Enhanced fitness conferred by naturally occurring variation in the circadian clock. Science 2003, 302, 1049-1053. [CrossRef] [PubMed]

11. Dodd, A.N.; Salathia, N.; Hall, A.; Kévei, E.; Tóth, R.; Nagy, F.; Hibberd, J.M.; Millar, A.J.; Webb, A.A. Plant circadian clocks increase photosynthesis, growth, survival, and competitive advantage. Science 2005, 309, 630-633. [CrossRef] [PubMed]

12. Mas, P. Circadian clock function in Arabidopsis thaliana: Time beyond transcription. Trends Cell Biol. 2008, 18, 273-281. [CrossRef] [PubMed]

13. Kinmonth-Schultz, H.A.; Golembeski, G.S.; Imaizumi, T. Circadian clock-regulated physiological outputs: Dynamic responses in nature. Semin. Cell Dev. Biol. 2013, 24, 407-413. [CrossRef] [PubMed]

14. Wang, Z.-Y.; Tobin, E.M. Constitutive expression of the CIRCADIAN CLOCK ASSOCIATED 1 (CCA1) gene disrupts circadian rhythms and suppresses its own expression. Cell 1998, 93, 1207-1217. [CrossRef]

15. Schaffer, R.; Ramsay, N.; Samach, A.; Corden, S.; Putterill, J.; Carré, I.A.; Coupland, G. The late elongated hypocotyl mutation of Arabidopsis disrupts circadian rhythms and the photoperiodic control of flowering. Cell 1998, 93, 1219-1229. [CrossRef]

16. Strayer, C.; Oyama, T.; Schultz, T.F.; Raman, R.; Somers, D.E.; Más, P.; Panda, S.; Kreps, J.A.; Kay, S.A. Cloning of the Arabidopsis clock gene TOC1, an autoregulatory response regulator homolog. Science 2000, 289, 768-771. [CrossRef] [PubMed]

17. Alabadí, D.; Oyama, T.; Yanovsky, M.J.; Harmon, F.G.; Más, P.; Kay, S.A. Reciprocal regulation between TOC1 and LHY/CCA1 within the Arabidopsis circadian clock. Science 2001, 293, 880-883. [CrossRef] [PubMed]

18. Gendron, J.M.; Pruneda-Paz, J.L.; Doherty, C.J.; Gross, A.M.; Kang, S.E.; Kay, S.A. Arabidopsis circadian clock protein, TOC1, is a DNA-binding transcription factor. Proc. Natl. Acad. Sci. USA 2012, 109, 3167-3172. [CrossRef] [PubMed]

19. Pokhilko, A.; Fernández, A.P.; Edwards, K.D.; Southern, M.M.; Halliday, K.J.; Millar, A.J. The clock gene circuit in Arabidopsis includes a repressilator with additional feedback loops. Mol. Syst. Biol. 2012, 8, 574. [CrossRef] [PubMed]

20. Huang, W.; Pérez-García, P.; Pokhilko, A.; Millar, A.; Antoshechkin, I.; Riechmann, J.L.; Mas, P. Mapping the core of the Arabidopsis circadian clock defines the network structure of the oscillator. Science 2012, 336, 75-79. [CrossRef] [PubMed]

21. Nakamichi, N.; Kiba, T.; Henriques, R.; Mizuno, T.; Chua, N.-H.; Sakakibara, H. PSEUDO-RESPONSE REGULATORS 9, 7, and 5 are transcriptional repressors in the Arabidopsis circadian clock. Plant Cell 2010, 22, 594-605. [CrossRef] [PubMed]

22. Wang, L.; Kim, J.; Somers, D.E. Transcriptional corepressor TOPLESS complexes with pseudoresponse regulator proteins and histone deacetylases to regulate circadian transcription. Proc. Natl. Acad. Sci. USA 2013, 110, 761-766. [CrossRef] [PubMed]

23. Helfer, A.; Nusinow, D.A.; Chow, B.Y.; Gehrke, A.R.; Bulyk, M.L.; Kay, S.A. LUX ARRHYTHMO encodes a nighttime repressor of circadian gene expression in the Arabidopsis core clock. Curr. Biol. 2011, 21, 126-133. [CrossRef] [PubMed]

24. Nusinow, D.A.; Helfer, A.; Hamilton, E.E.; King, J.J.; Imaizumi, T.; Schultz, T.F.; Farré, E.M.; Kay, S.A. The ELF4-ELF3-LUX complex links the circadian clock to diurnal control of hypocotyl growth. Nature 2011, 475, 398-402. [CrossRef] [PubMed]

25. Locke, J.C.; Kozma-Bognár, L.; Gould, P.D.; Fehér, B.; Kevei, E.; Nagy, F.; Turner, M.S.; Hall, A.; Millar, A.J. Experimental validation of a predicted feedback loop in the multi-oscillator clock of Arabidopsis thaliana. Mol. Syst. Biol. 2006, 2, 59. [CrossRef] [PubMed]

26. Más, P.; Kim, W.-Y.; Somers, D.E.; Kay, S.A. Targeted degradation of TOC1 by ZTL modulates circadian function in Arabidopsis thaliana. Nature 2003, 426, 567-570. [CrossRef] [PubMed]

27. Kiba, T.; Henriques, R.; Sakakibara, H.; Chua, N.-H. Targeted degradation of PSEUDO-RESPONSE REGULATOR5 by an SCF ${ }^{Z T L}$ complex regulates clock function and photomorphogenesis in Arabidopsis thaliana. Plant Cell 2007, 19, 2516-2530. [CrossRef] [PubMed] 
28. Kim, W.-Y.; Fujiwara, S.; Suh, S.-S.; Kim, J.; Kim, Y.; Han, L.; David, K.; Putterill, J.; Nam, H.G.; Somers, D.E. ZEITLUPE is a circadian photoreceptor stabilized by GIGANTEA in blue light. Nature 2007, 449, 356-360. [CrossRef] [PubMed]

29. Perales, M.; Mas, P. A functional link between rhythmic changes in chromatin structure and the Arabidopsis biological clock. Plant Cell. 2007, 19, 2111-2123. [CrossRef] [PubMed]

30. Farinas, B.; Mas, P. Functional implication of the MYB transcription factor RVE8/LCL5 in the circadian control of histone acetylation. Plant J. 2011, 66, 318-329. [CrossRef] [PubMed]

31. Rawat, R.; Takahashi, N.; Hsu, P.Y.; Jones, M.A.; Schwartz, J.; Salemi, M.R.; Phinney, B.S.; Harmer, S.L. REVEILLE8 and PSEUDO-REPONSE REGULATOR5 form a negative feedback loop within the Arabidopsis circadian clock. PLoS Genet. 2011, 7, e1001350. [CrossRef] [PubMed]

32. Hsu, P.Y.; Devisetty, U.K.; Harmer, S.L. Accurate timekeeping is controlled by a cycling activator in Arabidopsis. Elife 2013, 2, e00473. [CrossRef] [PubMed]

33. Xie, Q.; Wang, P.; Liu, X.; Yuan, L.; Wang, L.; Zhang, C.; Li, Y.; Xing, H.; Zhi, L.; Yue, Z. LNK1 and LNK2 are transcriptional coactivators in the Arabidopsis circadian oscillator. Plant Cell 2014, 2843-2857. [CrossRef] [PubMed]

34. Liu, T.; Newton, L.; Liu, M.-J.; Shiu, S.-H.; Farré, E.M. A G-box-like motif is necessary for transcriptional regulation by circadian pseudo-response regulators in Arabidopsis. Plant Physiol. 2015, 170, 528-539. [CrossRef] [PubMed]

35. Mizuno, T.; Kitayama, M.; Oka, H.; Tsubouchi, M.; Takayama, C.; Nomoto, Y.; Yamashino, T. The EC night-time repressor plays a crucial role in modulating circadian clock transcriptional circuitry by conservatively double-checking both warm-night and night-time-light signals in a synergistic manner in Arabidopsis thaliana. Plant Cell Physiol. 2014, 55, 2139-2151. [CrossRef] [PubMed]

36. Rugnone, M.L.; Soverna, A.F.; Sanchez, S.E.; Schlaen, R.G.; Hernando, C.E.; Seymour, D.K.; Mancini, E.; Chernomoretz, A.; Weigel, D.; Más, P. LNK genes integrate light and clock signaling networks at the core of the Arabidopsis oscillator. Proc. Natl. Acad. Sci. USA 2013, 110, 12120-12125. [CrossRef] [PubMed]

37. Mizuno, T.; Takeuchi, A.; Nomoto, Y.; Nakamichi, N.; Yamashino, T. The LNK1 night light-inducible and clock-regulated gene is induced also in response to warm-night through the circadian clock nighttime repressor in Arabidopsis thaliana. Plant Signal. Behav. 2014, 9, e28505. [CrossRef] [PubMed]

38. Ma, Y.; Gil, S.; Grasser, K.D.; Mas, P. Targeted recruitment of the basal transcriptional machinery by LNK clock components controls the circadian rhythms of nascent RNAs in Arabidopsis. Plant Cell 2018, 30, 907-924. [CrossRef] [PubMed]

39. Woodward, A.W.; Bartel, B. Auxin: Regulation, action, and interaction. Ann. Bot. 2005, 95, 707-735. [CrossRef] [PubMed]

40. Davies, P.J. Plant Hormones: Physiology, Biochemistry and Molecular Biology; Springer Science \& Business Media: Berlin, Germany, 2013.

41. Paponov, I.A.; Paponov, M.; Teale, W.; Menges, M.; Chakrabortee, S.; Murray, J.A.H.; Palme, K. Comprehensive transcriptome analysis of auxin responses in Arabidopsis. Mol. Plant 2008, 1, 321-337. [CrossRef] [PubMed]

42. Leyser, O. Auxin signaling. Plant Physiol. 2018, 176, 465-479. [CrossRef] [PubMed]

43. Estelle, M.; Weijers, D.; Ljung, K.; Leyser, O. Auxin Signaling: From Synthesis to Systems Biology; Cold Spring Harbor Laboratory Press: New York, NY, USA, 2011; p. 245.

44. Tiwari, S.B.; Hagen, G.; Guilfoyle, T.J. Aux/IAA proteins contain a potent transcriptional repression domain. Plant Cell 2004, 16, 533-543. [CrossRef] [PubMed]

45. Szemenyei, H.; Hannon, M.; Long, J.A. TOPLESS mediates auxin-dependent transcriptional repression during Arabidopsis embryogenesis. Science 2008, 319, 1384-1386. [CrossRef] [PubMed]

46. Shen-Miller, J. Rhythmicity in the basipetal transport of indoleacetic acid through coleoptiles. Plant Physiol. 1973, 51, 615-619. [CrossRef] [PubMed]

47. Jouve, L.; Gaspar, T.; Kevers, C.; Greppin, H.; Degli Agosti, R. Involvement of indole-3-acetic acid in the circadian growth of the first internode of Arabidopsis. Planta 1999, 209, 136-142. [CrossRef] [PubMed]

48. Covington, M.F.; Harmer, S.L. The circadian clock regulates auxin signaling and responses in Arabidopsis. PLoS Biol. 2007, 5, e222. [CrossRef] [PubMed] 
49. Rawat, R.; Schwartz, J.; Jones, M.A.; Sairanen, I.; Cheng, Y.; Andersson, C.R.; Zhao, Y.; Ljung, K.; Harmer, S.L. REVEILLE1, a Myb-like transcription factor, integrates the circadian clock and auxin pathways. Proc. Natl. Acad. Sci. USA 2009, 106, 16883-16888. [CrossRef] [PubMed]

50. Voß, U.; Wilson, M.H.; Kenobi, K.; Gould, P.D.; Robertson, F.C.; Peer, W.A.; Lucas, M.; Swarup, K.; Casimiro, I.; Holman, T.J. The circadian clock rephases during lateral root organ initiation in Arabidopsis thaliana. Nat. Commun. 2015, 6, 7641. [CrossRef] [PubMed]

51. Hong, L.-W.; Yan, D.-W.; Liu, W.-C.; Chen, H.-G.; Lu, Y.-T. TIME FOR COFFEE controls root meristem size by changes in auxin accumulation in Arabidopsis. J. Exp. Bot. 2013, 65, 275-286. [CrossRef] [PubMed]

52. Zha, P.; Jing, Y.; Xu, G.; Lin, R. PICKLE chromatin-remodeling factor controls thermosensory hypocotyl growth of Arabidopsis. Plant Cell Environ. 2017, 40, 2426-2436. [CrossRef] [PubMed]

53. Meyer, K.; Köster, T.; Nolte, C.; Weinholdt, C.; Lewinski, M.; Grosse, I.; Staiger, D. Adaptation of iCLIP to plants determines the binding landscape of the clock-regulated RNA-binding protein AtGRP7. Genome Biol. 2017, 18, 204. [CrossRef] [PubMed]

54. Hyunmo, C.; Eunkyoo, O. PIF4 integrates multiple environmental and hormonal signals for plant growth regulation in Arabidopsis. Mol. Cells 2016, 39, 587-593.

55. Nozue, K.; Harmer, S.L.; Maloof, J.N. Genomic analysis of circadian clock-, light-, and growth-correlated genes reveals PHYTOCHROME-INTERACTING FACTOR5 as a modulator of auxin signaling in Arabidopsis. Plant Physiol. 2011, 156, 357-372. [CrossRef] [PubMed]

56. Nomoto, Y.; Kubozono, S.; Yamashino, T.; Nakamichi, N.; Mizuno, T. Circadian clock-and PIF4-controlled plant growth: A coincidence mechanism directly integrates a hormone signaling network into the photoperiodic control of plant architectures in Arabidopsis thaliana. Plant Cell Physiol. 2012, 53, 1950-1964. [CrossRef] [PubMed]

57. Kunihiro, A.; Yamashino, T.; Nakamichi, N.; Niwa, Y.; Nakanishi, H.; Mizuno, T. Phytochrome-interacting factor 4 and 5 (PIF4 and PIF5) activate the homeobox ATHB2 and auxin-inducible IAA29 genes in the coincidence mechanism underlying photoperiodic control of plant growth of Arabidopsis thaliana. Plant Cell Physiol. 2011, 52, 1315-1329. [CrossRef] [PubMed]

58. Zhu, J.-Y.; Oh, E.; Wang, T.; Wang, Z.-Y. TOC1-PIF4 interaction mediates the circadian gating of thermoresponsive growth in Arabidopsis. Nat. Commun. 2016, 7, 13692. [CrossRef] [PubMed]

59. Raschke, A.; Ibañez, C.; Ullrich, K.K.; Anwer, M.U.; Becker, S.; Glöckner, A.; Trenner, J.; Denk, K.; Saal, B.; Sun, X. Natural variants of ELF3 affect thermomorphogenesis by transcriptionally modulating PIF4-dependent auxin response genes. BMC Plant Biol. 2015, 15, 197. [CrossRef] [PubMed]

60. Hanano, S.; Domagalska, M.A.; Nagy, F.; Davis, S.J. Multiple phytohormones influence distinct parameters of the plant circadian clock. Genes Cells 2006, 11, 1381-1392. [CrossRef] [PubMed]

61. Hearn, T.J.; Marti, M.C.; Abdul-Awal, S.; Wimalasekera, R.; Stanton, C.R.; Haydon, M.J.; Theodoulou, F.L.; Hannah, M.A.; Webb, A.A. BIG regulates dynamic adjustment of circadian period in Arabidopsis thaliana. Plant Physiol. 2018, 178, 358-371. [CrossRef] [PubMed]

62. Gil, P.; Dewey, E.; Friml, J.; Zhao, Y.; Snowden, K.C.; Putterill, J.; Palme, K.; Estelle, M.; Chory, J. BIG: A calossin-like protein required for polar auxin transport in Arabidopsis. Genes Dev. 2001, 15, $1985-1997$. [CrossRef] [PubMed]

63. Kieber, J.J.; Schaller, G.E. Cytokinins. In The Arabidopsis Book; American Society of Plant Biologists: Rockville, MD, USA, 2014; p. 12.

64. Ha, S.; Vankova, R.; Yamaguchi-Shinozaki, K.; Shinozaki, K.; Tran, L.-S.P. Cytokinins: Metabolism and function in plant adaptation to environmental stresses. Trends Plant Sci. 2012, 17, 172-179. [CrossRef] [PubMed]

65. Kakimoto, T. Biosynthesis of cytokinins. J. Plant Res. 2003, 116, 233-239. [CrossRef] [PubMed]

66. Werner, T.; Köllmer, I.; Bartrina, I.; Holst, K.; Schmülling, T. New insights into the biology of cytokinin degradation. Plant Biol. 2006, 8, 371-381. [CrossRef] [PubMed]

67. Inoue, T.; Higuchi, M.; Hashimoto, Y.; Seki, M.; Kobayashi, M.; Kato, T.; Tabata, S.; Shinozaki, K.; Kakimoto, T. Identification of CRE1 as a cytokinin receptor from Arabidopsis. Nature 2001, 409, 1060-1063. [CrossRef] [PubMed]

68. Suzuki, T.; Miwa, K.; Ishikawa, K.; Yamada, H.; Aiba, H.; Mizuno, T. The Arabidopsis sensor His-kinase, AHK4, can respond to cytokinins. Plant Cell Physiol. 2001, 42, 107-113. [CrossRef] [PubMed] 
69. Heyl, A.; Riefler, M.; Romanov, G.A.; Schmülling, T. Properties, functions and evolution of cytokinin receptors. Eur. J. Cell Biol. 2012, 91, 246-256. [CrossRef] [PubMed]

70. Heyl, A.; Schmülling, T. Cytokinin signal perception and transduction. Curr. Opin. Plant Biol. 2003, 6, 480-488. [CrossRef]

71. Dortay, H.; Mehnert, N.; Bürkle, L.; Schmülling, T.; Heyl, A. Analysis of protein interactions within the cytokinin-signaling pathway of Arabidopsis thaliana. FEBS J. 2006, 273, 4631-4644. [CrossRef] [PubMed]

72. Covington, M.F.; Maloof, J.N.; Straume, M.; Kay, S.A.; Harmer, S.L. Global transcriptome analysis reveals circadian regulation of key pathways in plant growth and development. Genome Biol. 2008, 9, R130. [CrossRef] [PubMed]

73. Zheng, B.; Deng, Y.; Mu, J.; Ji, Z.; Xiang, T.; Niu, Q.W.; Chua, N.H.; Zuo, J. Cytokinin affects circadian-clock oscillation in a phytochrome B-and Arabidopsis response regulator 4-dependent manner. Physiol. Plant. 2006, 127, 277-292. [CrossRef]

74. Nováková, M.; Motyka, V.; Dobrev, P.I.; Malbeck, J.; Gaudinová, A.; Vanková, R. Diurnal variation of cytokinin, auxin and abscisic acid levels in tobacco leaves. J. Exp. Bot. 2005, 56, 2877-2883. [CrossRef] [PubMed]

75. Ezer, D.; Jung, J.-H.; Lan, H.; Biswas, S.; Gregoire, L.; Box, M.S.; Charoensawan, V.; Cortijo, S.; Lai, X.; Stöckle, D. The evening complex coordinates environmental and endogenous signals in Arabidopsis. Nat. Plants 2017, 3, 17087. [CrossRef] [PubMed]

76. Ishida, K.; Yamashino, T.; Mizuno, T. Expression of the cytokinin-induced type-A response regulator gene ARR9 is regulated by the circadian clock in Arabidopsis thaliana. Biosci. Biotechnol. Biochem. 2008, 72, 3025-3029. [CrossRef] [PubMed]

77. Putarjunan, A.; Rodermel, S. Gigantea suppresses immutans variegation by interactions with cytokinin and GA signaling pathways. Plant Physiol. 2014, 166, 2115-2132. [CrossRef] [PubMed]

78. Salomé, P.A.; To, J.P.; Kieber, J.J.; McClung, C.R. Arabidopsis response regulators ARR3 and ARR4 play cytokinin-independent roles in the control of circadian period. Plant Cell 2006, 18, 55-69. [CrossRef] [PubMed]

79. Nitschke, S.; Cortleven, A.; Iven, T.; Feussner, I.; Havaux, M.; Riefler, M.; Schmülling, T. Circadian stress regimes affect the circadian clock and cause jasmonic acid-dependent cell death in cytokinin-deficient Arabidopsis plants. Plant Cell 2016, 28, 1616-1639. [CrossRef] [PubMed]

80. Salomé, P.A.; Michael, T.P.; Kearns, E.V.; Fett-Neto, A.G.; Sharrock, R.A.; McClung, C.R. The out of phase 1 mutant defines a role for PHYB in circadian phase control in Arabidopsis. Plant Physiol. 2002, 129, 1674-1685. [CrossRef] [PubMed]

81. Leung, J.; Giraudat, J. Abscisic acid signal transduction. Annu. Rev. Plant Biol. 1998, 49, 199-222. [CrossRef] [PubMed]

82. Finkelstein, R.R.; Gampala, S.S.; Rock, C.D. Abscisic acid signaling in seeds and seedlings. Plant Cell 2002, 14, S15-S45. [CrossRef] [PubMed]

83. Thompson, A.J.; Mulholland, B.J.; Jackson, A.C.; McKee, J.M.; Hilton, H.W.; Symonds, R.C.; Sonneveld, T.; Burbidge, A.; Stevenson, P.; Taylor, I.B. Regulation and manipulation of ABA biosynthesis in roots. Plant Cell Environ. 2007, 30, 67-78. [CrossRef] [PubMed]

84. Verslues, P.E.; Zhu, J.-K. New developments in abscisic acid perception and metabolism. Curr. Opin. Plant Biol. 2007, 10, 447-452. [CrossRef] [PubMed]

85. Guo, J.; Yang, X.; Weston, D.J.; Chen, J.G. Abscisic acid receptors: Past, present and future F. J. Integr. Plant Biol. 2011, 53, 469-479. [CrossRef] [PubMed]

86. Hirayama, T.; Shinozaki, K. Perception and transduction of abscisic acid signals: Keys to the function of the versatile plant hormone ABA. Trends Plant Sci. 2007, 12, 343-351. [CrossRef] [PubMed]

87. Park, S.-Y.; Fung, P.; Nishimura, N.; Jensen, D.R.; Fujii, H.; Zhao, Y.; Lumba, S.; Santiago, J.; Rodrigues, A.; Tsz-fung, F.C. Abscisic acid inhibits type 2C protein phosphatases via the PYR/PYL family of START proteins. Science 2009, 324, 1068-1071. [CrossRef] [PubMed]

88. Ma, Y.; Szostkiewicz, I.; Korte, A.; Moes, D.; Yang, Y.; Christmann, A.; Grill, E. Regulators of PP2C phosphatase activity function as abscisic acid sensors. Science 2009, 324, 1064-1068. [CrossRef] [PubMed] 
89. Kobayashi, Y.; Murata, M.; Minami, H.; Yamamoto, S.; Kagaya, Y.; Hobo, T.; Yamamoto, A.; Hattori, T. Abscisic acid-activated SNRK2 protein kinases function in the gene-regulation pathway of ABA signal transduction by phosphorylating ABA response element-binding factors. Plant J. 2005, 44, 939-949. [CrossRef] [PubMed]

90. Hubbard, K.E.; Nishimura, N.; Hitomi, K.; Getzoff, E.D.; Schroeder, J.I. Early abscisic acid signal transduction mechanisms: Newly discovered components and newly emerging questions. Genes Dev. 2010, 24, 1695-1708. [CrossRef] [PubMed]

91. Mizuno, T.; Yamashino, T. Comparative transcriptome of diurnally oscillating genes and hormone-responsive genes in Arabidopsis thaliana: Insight into circadian clock-controlled daily responses to common ambient stresses in plants. Plant Cell Physiol. 2008, 49, 481-487. [CrossRef] [PubMed]

92. Adams, S.; Grundy, J.; Veflingstad, S.R.; Dyer, N.P.; Hannah, M.A.; Ott, S.; Carré, I.A. Circadian control of abscisic acid biosynthesis and signalling pathways revealed by genome-wide analysis of LHY binding targets. New Phytol. 2018, 220, 893-907. [CrossRef] [PubMed]

93. Choudhary, M.K.; Nomura, Y.; Wang, L.; Nakagami, H.; Somers, D.E. Quantitative circadian phosphoproteomic analysis of Arabidopsis reveals extensive clock control of key components in physiological, metabolic and signaling pathways. Mol. Cell. Proteom. 2015, 14, 2243-2260. [CrossRef] [PubMed]

94. Greenham, K.; Guadagno, C.R.; Gehan, M.A.; Mockler, T.C.; Weinig, C.; Ewers, B.E.; McClung, C.R. Temporal network analysis identifies early physiological and transcriptomic indicators of mild drought in Brassica rapa. eLife 2017, 6, e29655. [CrossRef] [PubMed]

95. Legnaioli, T.; Cuevas, J.; Mas, P. TOC1 functions as a molecular switch connecting the circadian clock with plant responses to drought. EMBO J. 2009, 28, 3745-3757. [CrossRef] [PubMed]

96. Robertson, F.C.; Skeffington, A.W.; Gardner, M.J.; Webb, A.A. Interactions between circadian and hormonal signalling in plants. Plant Mol. Biol. 2009, 69, 419. [CrossRef] [PubMed]

97. Kurup, S.; Jones, H.D.; Holdsworth, M.J. Interactions of the developmental regulator ABI3 with proteins identified from developing Arabidopsis seeds. Plant J. 2000, 21, 143-155. [CrossRef] [PubMed]

98. Lee, H.G.; Mas, P.; Seo, P.J. MYB96 shapes the circadian gating of ABA signaling in Arabidopsis. Sci. Rep. 2016, 6, 17754. [CrossRef] [PubMed]

99. Dodd, A.N.; Gardner, M.J.; Hotta, C.T.; Hubbard, K.E.; Dalchau, N.; Love, J.; Assie, J.-M.; Robertson, F.C.; Jakobsen, M.K.; Gonçalves, J. The Arabidopsis circadian clock incorporates a cADPR-based feedback loop. Science 2007, 318, 1789-1792. [CrossRef] [PubMed]

100. Sánchez, J.P.; Duque, P.; Chua, N.H. ABA activates ADPR cyclase and cADPR induces a subset of ABA-responsive genes in Arabidopsis. Plant J. 2004, 38, 381-395. [CrossRef] [PubMed]

101. Fukushima, A.; Kusano, M.; Nakamichi, N.; Kobayashi, M.; Hayashi, N.; Sakakibara, H.; Mizuno, T.; Saito, K. Impact of clock-associated Arabidopsis pseudo-response regulators in metabolic coordination. Proc. Natl. Acad. Sci. USA 2009, 106, 7251-7256. [CrossRef] [PubMed]

102. Sanchez-Villarreal, A.; Shin, J.; Bujdoso, N.; Obata, T.; Neumann, U.; Du, S.X.; Ding, Z.; Davis, A.M.; Shindo, T.; Schmelzer, E. TIME FOR COFFEE is an essential component in the maintenance of metabolic homeostasis in Arabidopsis thaliana. Plant J. 2013, 76, 188-200. [PubMed]

103. Mir, R.; Hernández, M.L.; Abou-Mansour, E.; Martínez-Rivas, J.M.; Mauch, F.; Métraux, J.-P.; León, J. Pathogen and Circadian Controlled 1 (PCC1) regulates polar lipid content, ABA-related responses, and pathogen defence in Arabidopsis thaliana. J. Exp. Bot. 2013, 64, 3385-3395. [CrossRef] [PubMed]

104. Footitt, S.; Ölçer-Footitt, H.; Hambidge, A.J.; Finch-Savage, W.E. A laboratory simulation of Arabidopsis seed dormancy cycling provides new insight into its regulation by clock genes and the dormancy-related genes DOG1, MFT, CIPK23 and PHYA. Plant Cell Environ. 2017, 40, 1474-1486. [CrossRef] [PubMed]

105. Penfield, S.; Hall, A. A role for multiple circadian clock genes in the response to signals that break seed dormancy in Arabidopsis. Plant Cell 2009, 21, 1722-1732. [CrossRef] [PubMed]

106. Cao, S.; Jiang, L.; Song, S.; Jing, R.; Xu, G. AtGRP7 is involved in the regulation of abscisic acid and stress responses in Arabidopsis. Cell. Mol. Biol. Lett. 2006, 11, 526. [CrossRef] [PubMed]

107. Riboni, M.; Robustelli Test, A.; Galbiati, M.; Tonelli, C.; Conti, L. ABA-dependent control of GIGANTEA signalling enables drought escape via up-regulation of FLOWERING LOCUS T in Arabidopsis thaliana. J. Exp. Bot. 2016, 67, 6309-6322. [CrossRef] [PubMed]

108. Broekgaarden, C.; Caarls, L.; Vos, I.A.; Pieterse, C.M.; Van Wees, S.C. Ethylene: Traffic controller on hormonal crossroads to defense. Plant Physiol. 2015, 169, 2371-2379. [CrossRef] [PubMed] 
109. Broekaert, W.F.; Delauré, S.L.; De Bolle, M.F.; Cammue, B.P. The role of ethylene in host-pathogen interactions. Annu. Rev. Phytopathol. 2006, 44, 393-416. [CrossRef] [PubMed]

110. Dubois, M.; Van den Broeck, L.; Inzé, D. The pivotal role of ethylene in plant growth. Trends Plant Sci. 2018, 23, 311-323. [CrossRef] [PubMed]

111. Barry, C.S.; Giovannoni, J.J. Ethylene and fruit ripening. J. Plant Growth Regul. 2007, 26, 143. [CrossRef]

112. Zhong, S.; Shi, H.; Xue, C.; Wang, L.; Xi, Y.; Li, J.; Quail, P.H.; Deng, X.W.; Guo, H. A molecular framework of light-controlled phytohormone action in Arabidopsis. Curr. Biol. 2012, 22, 1530-1535. [CrossRef] [PubMed]

113. García, M.J.; Romera, F.J.; Lucena, C.; Alcántara, E.; Pérez-Vicente, R. Ethylene and the regulation of physiological and morphological responses to nutrient deficiencies. Plant Physiol. 2015, 169, 51-60. [CrossRef] [PubMed]

114. Clark, K.L.; Larsen, P.B.; Wang, X.; Chang, C. Association of the Arabidopsis CTR1 Raf-like kinase with the ETR1 and ERS ethylene receptors. Proc. Natl. Acad. Sci. USA 1998, 95, 5401-5406. [CrossRef] [PubMed]

115. Shakeel, S.; Gao, Z.; Amir, M.; Chen, Y.-F.; Rai, M.I.; Haq, N.U.; Schaller, G.E. Ethylene regulates levels of ethylene-receptor/CTR1 signaling complexes in Arabidopsis thaliana. J. Biol. Chem. 2015, 290, 12415-12424. [CrossRef] [PubMed]

116. Potuschak, T.; Lechner, E.; Parmentier, Y.; Yanagisawa, S.; Grava, S.; Koncz, C.; Genschik, P. EIN3-dependent regulation of plant ethylene hormone signaling by two Arabidopsis F box proteins: EBF1 and EBF2. Cell 2003, 115, 679-689. [CrossRef]

117. Guo, H.; Ecker, J.R. Plant responses to ethylene gas are mediated by SCFEBF1/EBF2 dependent proteolysis of EIN3 transcription factor. Cell 2003, 115, 667-677. [CrossRef]

118. Thain, S.C.; Vandenbussche, F.; Laarhoven, L.J.; Dowson-Day, M.J.; Wang, Z.-Y.; Tobin, E.M.; Harren, F.J.; Millar, A.J.; Van Der Straeten, D. Circadian rhythms of ethylene emission in Arabidopsis. Plant Physiol. 2004, 136, 3751-3761. [CrossRef] [PubMed]

119. Ellison, C.T.; Vandenbussche, F.; Van Der Straeten, D.; Harmer, S.L. XAP5 CIRCADIAN TIMEKEEPER regulates ethylene responses in aerial tissues of Arabidopsis. Plant Physiol. 2010, 155, 988-999. [CrossRef] [PubMed]

120. Xu, Y.-J.; Lei, Y.; Li, R.; Zhang, L.-L.; Zhao, Z.-X.; Zhao, J.-H.; Fan, J.; Li, Y.; Yang, H.; Shang, J. XAP5 CIRCADIAN TIMEKEEPER positively regulates RESISTANCE TO POWDERY MILDEW8. 1-mediated immunity in Arabidopsis. Front. Plant Sci. 2017, 8, 2044. [CrossRef] [PubMed]

121. Song, Q.; Ando, A.; Xu, D.; Fang, L.; Zhang, T.; Huq, E.; Qiao, H.; Deng, X.W.; Chen, Z.J. Diurnal down-regulation of ethylene biosynthesis mediates biomass heterosis. Proc. Natl. Acad. Sci. USA 2018, 115, 5606-5611. [CrossRef] [PubMed]

122. Haydon, M.J.; Mielczarek, O.; Frank, A.; Román, Á.; Webb, A.A. Sucrose and ethylene signaling interact to modulate the circadian clock. Plant Physiol. 2017, 175, 947-958. [CrossRef] [PubMed]

123. Davière, J.-M.; Achard, P. Gibberellin signaling in plants. Development 2013, 140, 1147-1151. [CrossRef] [PubMed]

124. Bolle, C. The role of GRAS proteins in plant signal transduction and development. Planta 2004, 218, 683-692. [CrossRef] [PubMed]

125. Davière, J.-M.; Achard, P. A pivotal role of DELLAs in regulating multiple hormone signals. Mol. Plant 2016, 9, 10-20. [CrossRef] [PubMed]

126. Feng, S.; Martinez, C.; Gusmaroli, G.; Wang, Y.; Zhou, J.; Wang, F.; Chen, L.; Yu, L.; Iglesias-Pedraz, J.M.; Kircher, S. Coordinated regulation of Arabidopsis thaliana development by light and gibberellins. Nature 2008, 451, 475-479. [CrossRef] [PubMed]

127. Sun, T.-P. The molecular mechanism and evolution of the GA-GID1-DELLA signaling module in plants. Curr. Biol. 2011, 21, R338-R345. [CrossRef] [PubMed]

128. Ueguchi-Tanaka, M.; Ashikari, M.; Nakajima, M.; Itoh, H.; Katoh, E.; Kobayashi, M.; Chow, T.-Y.; Yue-ie, C.H.; Kitano, H.; Yamaguchi, I. GIBBERELLIN INSENSITIVE DWARF1 encodes a soluble receptor for gibberellin. Nature 2005, 437, 693-698. [CrossRef] [PubMed]

129. Ariizumi, T.; Murase, K.; Sun, T.-P.; Steber, C.M. Proteolysis-independent downregulation of DELLA repression in Arabidopsis by the gibberellin receptor GIBBERELLIN INSENSITIVE DWARF1. Plant Cell 2008, 20, 2447-2459. [CrossRef] [PubMed]

130. Arana, M.V.; Marín-de la Rosa, N.; Maloof, J.N.; Blázquez, M.A.; Alabadí, D. Circadian oscillation of gibberellin signaling in Arabidopsis. Proc. Natl. Acad. Sci. USA 2011, 108, 9292-9297. [CrossRef] [PubMed] 
131. Filo, J.; Wu, A.; Eliason, E.; Richardson, T.; Thines, B.C.; Harmon, F.G. Gibberellin driven growth in elf3 mutants requires PIF4 and PIF5. Plant Signal. Behav. 2015, 10, e992707. [CrossRef] [PubMed]

132. Zheng, H.; Zhang, F.; Wang, S.; Su, Y.; Jiang, P.; Cheng, R.; Ji, X.; Hou, S.; Ding, Y. MLK1 and MLK2 coordinate RGA and CCA1 activity to regulate hypocotyl elongation in Arabidopsis thaliana. Plant Cell 2017, 30, 67-82. [CrossRef] [PubMed]

133. Tseng, T.-S.; Salomé, P.A.; McClung, C.R.; Olszewski, N.E. SPINDLY and GIGANTEA interact and act in Arabidopsis thaliana pathways involved in light responses, flowering, and rhythms in cotyledon movements. Plant Cell 2004, 16, 1550-1563. [CrossRef] [PubMed]

(C) 2018 by the authors. Licensee MDPI, Basel, Switzerland. This article is an open access article distributed under the terms and conditions of the Creative Commons Attribution (CC BY) license (http:/ / creativecommons.org/licenses/by/4.0/). 